\title{
Dinamika Resiliensi Pada Istri yang Menjadi Korban Perselingkuhan Suami
}

\author{
Andreas Corsini Widya Nugraha ${ }^{1,{ }^{*}}$, Hanna Rahmi ${ }^{1}$ \\ ${ }^{1}$ Fakultas Psikologi; Universitas Bhayangkara Jakarta Raya; Jl Raya Perjuangan \\ Marga Mulya, Bekasi Utara, Jawa Barat 17121, Telp: 021-88955882, 889955883; e-mail: \\ andreas.corsini@dsn.ubharajaya.ac.id, hanna.rahmi@dsn.ubharajaya.ac.id \\ * Korespondensi: e-mail: andreas.corsini@dsn.ubharajaya.ac.id \\ Submitted: 13/11/2020; Revised: 30/12/2020; Accepted: 06/01/2021; Published: 15/01/2021
}

\begin{abstract}
Marriage is basically building a sacred bond in which there are two persons united with a commitment to living together for all time. Every couple crave a harmonious relationship, get warmth, and eternal affection. But sometimes the desired happiness can not be realized, because of the various problems that overshadow in the world of marriage one of which is infidelity. The study used a qualitative case study approach with 2 research subjects. Something that is unique in this study is when the phenomenon of infidelity involving a husband, but the household can still be maintained. The resilience mechanism found in wives who are victims of husband infidelity is the "reaching out" model, namely healing from trauma by searching for more positive life experiences.
\end{abstract}

Keywords: Case studies, Infidelity, Resilience, Reaching Out

\begin{abstract}
Abstrak
Pernikahan pada dasarnya adalah membangun sebuah ikatan suci dimana ada dua pribadi yang disatukan dengan komitmen hidup bersama sepanjang masa. Setiap pasangan mendambakan hubungan yang harmonis, mendapat kehangatan, dan kasih sayang yang abadi. Namun terkadang pernikahan yang bahagia tidak terwujud, karena berbagai permasalahan yang mambayangi dalam dunia pernikahan salah satunya adalah perselingkuhan. Penelitian menggunakan pendekatan kualitatif studi kasus dengan 2 subjek penelitian. Sesuatu yang unik pada penelitian ini adalah ketika terjadi fenomena perselingkuhan yang melibatkan suami, tetapi rumah tangga masih bisa dipertahankan. Mekanisme resiliensi yang ditemukan pada istri yang menjadi korban perselingkuhan suami adalah model "reaching out", yaitu penyembuhan dari trauma dengan mencari pengalaman hidup yang lebih positif.
\end{abstract}

Kata kunci: Studi Kasus, Perselingkuhan, Resiliensi, Reaching Out

\section{Pendahuluan}

Tahap tahap perkembangan manusia memiliki fase yang cukup panjang. Salah satu fase pada taraf perkembangan manusia ketika memasuki masa dewasa awal adalah berkaitan dengan pernikahan, dimana individu-individu yang telah menyelesaikan pertumbuhannya dan siap menerima statusnya di lingkungan sosial bersama-sama orang-orang dewasa lainnya. Perkembangan sosial masa dewasa awal adalah puncak dari perkembangan sosial masa dewasa.Pada masa ini adalah masa beralihnya pandangan egosentris menjadi sikap yang empati, dimana penentuan relasi sangat memegang peranan penting (Santrock, 2002). 
Fenomena permasalahan berkaitan dengan pernikahan sering muncul dan terjadi, sehingga pernikahan tidak melahirkan kebahagiaan dari suami istri. Menurut data Komisi Nasional Perempuan tahun 2018 ada 348.446 kasus kekerasan perempuan yang ditangani dan dilaporkan selama tahun 2017.Selain itu dari data BPS ditemukan 347.256 kasus perceraian yang terjadi pada tahun 2017 dari 1.958 .394 pernikahan. Berdasarkan penelitian analisis faktor penyebab perceraian yang terjadi pada pernikahan salah satu penyebabnya adalah berkaitan dengan perselisihan yang diakibatkan adanya gangguan pihak ketiga, atau lebih tepatnya perselingkuhan. Tidak dapat dipungkiri bahwa kehadiran orang ketiga menjadi salah satu penyebab ketidakharmonisan dan perselisihan di dalam kehidupan rumah tangga yang dapat mengakibatkan perceraian (Catatan Tahunan (CATAHU) Komnas Perempuan Tahun, 2018).

Data tahun 2005 di Jawa Timur sebagai salah satu provinsi yang mencatatkan kasus perceraian tertinggi di Indonesia menyebutkan bahwa 13.779 kasus perceraian yang terjadi di provinsi itu, sebanyak 9.071 kasus dikarenakan adanya orang ketiga dalam hubungan pernikahan, dan beberapa kasus lain sejumlah 4.708 dikarenakan cemburu (Widayanti, 2014) . $\mathrm{Hal}$ ini menunjukkan bahwa permasalahan pernikahan berkaitan dengan perselingkuhan dan juga cemburu memberikan dampak yang cukup signifikan terhadap retaknya kehidupan dalam berumah tangga.

Pada fenomena pokok bahasan penilitian ini akan menggali tentang fenomena perselingkuhan yang dilakukan oleh suami, dimana hal ini terjadi sepanjang rentang pernikahan yang sudah terjadi lebih dari 20 tahun. Sesuatu yang unik pada penelitian ini adalah ketika terjadi fenomena perselingkuhan terjadi yang melibatkan suami, tetapi rumah tangga masih bisa dipertahankan walaupun istri mengetahuinya. Pada umumnya ketika terjadi perselingkuhan, biasanya akan menuju pada gerbang perceraian.

Pada kasus tertentu didalam perselingkuhan ada beberapa rumah tangga yang masih bisa dipertahankan, Bahwa wanita mungkin lebih berupaya untuk memperbaiki hubungan dan mempertahankan, sedangkan laki-laki lebih ada kecenderungan untuk mengakhiri sebuah hubungan dikarenakan laki-laki berpikiran bahwa akan lebih mudah untuk mencari pengganti. Dapat diartikan reaksi yang ketika perselingkuhan terjadi bisa ada dua macam, yang pertama adalah reaksi destruksi dan juga reaksi konstruksi, reaksi destruksi akan membawa pernikahan pada perceraian,sebaliknya reaksi konstruksi akan membawa sebuah pernikahan pada situasi konflik menjadi lebih baik, dan ada kecenderungan untuk mempertahankan sebuah pernikahan,walaupun pada kondisi yang kurang baik. Sesuatu yang penulis anggap unik adalah faktor yang menyebabkan istri mampu bertahan pada sebuah pernikahan yang penuh dengan tekanan batin, padahal sebagian besar istri lebih memilih menyudahi pernikahan dengan jalan perceraian (Spring, 2012).

Pada dasarnya kehidupan dipenuhi berbagai pengalaman yang penuh dengan penderitaan (adversity), sebagai adversity bersumber dari situasi eksternal misalnya bencana alam atau situasi-situasi lain misalnya keluarga perceraian, kehilangan pekerjaan,kehilangan tempat tinggal, kehilangan orang yang dicintai. Selain faktor eksternal timbulnya penderitaan bisa 
berasal dari individu itu sendiri misalnya perasaan takut, rasa bersalah, merasa dikucilkan oleh orang yang berada di sekitar, kegagalan atau sedang diserang penyakit (Grotberg, 1995).

Resiliensi adalah proses dimana individu akan mempunyai kemauan untuk bangkit dalam sebuah tekanan hidup(Henderson, N. Dan Milstein, 2003). Pengertian lain menyebutkan definisi dari resiliensi adalah merupakan proses dinamis dimana individu menunjukkan fungsi adaptif dalam menghadapi adversity yang berperan penting bagi pribadi(Schoon, 2006).

Resiliensi sebagai kemampuan pola pikir yang memungkinkan manusia mencari pengalaman dan memandang hidupya sebagai sesuatu yang sedang berjalan. Resiliensi memberikan rasa percaya diri untuk mengambil tanggung jawab baru dalam menjalani sebuah pekerjaan (Amacon. Reivich, K., \& Shatte, 2002).

Sumber-sumber resiliensi meliputi beberapa hal sebagai berikut, pertama faktor kepribadian, faktor kepribadian meliputi karakteristik kepribadian, self efficacy, self esteem, internal locus of control, optimisme, kapasitas intelektual, konsep diri positif, faktor demografi (usia, jenis kelamin dan suku) harapan dan ketangguhan, regulasi emosi dan sebagainya. Kedua adalah neurobiologis, yaitu lingkungan awal akan mempengaruhi perkembangan dan struktur otak serta sistem neurobiologis. Ketiga adalah faktor lingkungan yaitu relasi dengan keluarga dan teman sebaya, secure attachment pada ibu dan kestabilan keluarga (Herrman, H., Stewart, D. E., Diaz-Granados, N., Berger, E. L., Jackson, B., \& Yuen, 2011).

Bahwa meningkatkan resiliensi adalah tugas yang penting karena hal ini dapat memberikan pengalaman bagi manusia dalam menghadapi tantangan dan kesuitan hidup. Dengan meningkatkan resiliensi, manusia dapat mengembangkan keterampilan hidup seperti bagaimana berkomunikasi, kemampuan yang realistic dalam membuat rencana hidup dan mampu mengambil langkah tepat bagi hidupnya. Hal ini bertujuan untuk mengembangkan keadaan yang penuh tekanan menjadi sebuah kesempatan untu pengembangan diri pribadi (Fernanda Rojas, 2015).

Beberapa aspek yang ada di dalam resiliensi antara lain regulasi emosi, pengendalian impuls, optimism,empati, analisis penyebab masalah, efikasi diri, dan reaching out. Hampir tidak ada satupun individu secara keseluruhan memiliki tujuh kemampuan tersebut dengan baik (Amacon. Reivich, K., \& Shatte, 2002). Resiliensi sangat diperlukan ketika seseorang mengalami masalah pada setiap harinya. Berkaitan dengan penelitian yang akan diangkat yaitu resiliensi istri yang menjadi korban perselingkuhan, hal yang unik dari kasus perselingkuhan yang terjadi adalah bagaimana yang bersangkutan masih dapat mempertahankan rumah tangganya.

Perselingkuhan merupakan hubungan antara seseorang yang berkeluarga dan menikah dengan orang lain yang bukan merupakan suami/istri yang sah. Hubungan perselingkuhan dapat terbatas pada hubungan emosional yang dekat dan terkadang melibatkan hubungan seksual (Subotnik, R.B., \& Harris, 2005). Ada 3 komponen dari perselingkuhan emosional yaitu, keintiman emosional, kerahasiaan, dan seksual chemistry. Dalam perselingkuhan hubungan hubungan seksual tidak selalu muncul, tetapi hubungan tetap berpotensi untuk membahayakan dikarenakan membahayakan keutuhan perkawinan, karena hubungan bisa menjadi lebih penting 
dibandingkan dengan perkawinan itu sendiri (Glass, S. P. \& Staeheli, 2003). Beberapa bentuk perselingkuhan antara lain:

a. Serial Affair

Tipe perselingkuhan ini paling sedikit melibatkan keintiman emosional tetapi terjadi berkalikali. Hubungan yang terbentuk dapat berupa perselingkuhan semalam atau sejumlah affair yang berlangsung cukup lama. Serial Affair tidak terdapat keterlibatan emosional, hubungan dijalin dengan tujuan mendapatkan kenikmatan dan kebebasan.Inti dari model perselingkuhan ini adalah untuk mendapatkan kepuasan seksual. Tidak melibatkan keterlibatan emosional yang terjalin diantara pasangan, tidak dapat diartikan model perselingkuhan ini tidak membahayakan. Beberapa resiko yang dihadapi adalah adanya penularan penyakit seksual.

b. Flings

Hubungan model flings ini minim juga keterlibatan emosional. Hubungan dapat berupa perselingkuhan yang terjadi dalam satu malam, hubungan hanya terjadi selama beberapa bulan, yang terjadi hanya sekali saja. Flings memiliki dampak yang lebih ringan dibandingkan dengan jenis perselingkuhan yang lain.

c. Romantic Love Affair

Perselingkuhan tipe ini melibatkan hubungan emosional yang dalam. Hubungan menjadi sangat penting sekali khususnya dalam kehidupan pasangan. Dalam beberapa kasus beberapa pasangan ingin meninggalkan pasangan resminya dan menikahi pasangan selingkuhnya.Pada kasus tertentu jika perceraian tidak memungkinkan, maka perselingkuhan tersebut dapat berlangsung selama jangka panjang.

d. Long Term Affair

Pada hubungan ini keterlibatan emosional terjadi paling mendalam. Hubungan terjadi selama bertahun-tahun dan bahkan sepanjang kehidupan perkawinan.Pada beberapa pasangan merasa hubungan dengan pasangan selingkuhnya lebih menyenangkan daripada dengan suami atau istri yang sah.Umumnya perselingkuhan ini berlangsung lama dan tidak jarang hubungan dapat diketahui oleh pihak istri atau pihak suami yang resmi (Subotnik, R.B., \& Harris, 2005)

Ada perbedaan dari sisi wanita dan pria, jika pria lebih mengutamakan perselingkuhan yang disertai dengan hubungan seksual, berbeda dengan wanita, wanita berselingkuh untuk memperoleh kedekatan secara emosional(Eaves, S. H., \& Robertson-Smith, 2007). Beberapa faktor yang melibatkan perselingkuhan antara lain ketidakpuasan dalam hubungan pernikahan, tetapi ada beberapa faktor lain di luar perkawinan yang mempengaruhi adanya orang ketiga di dalam sebuah perkawinan.

Beberapa hal yang menyebabkan masuknya orang ketiga dalam perkawinan antara lain (Eaves, S. H., \& Robertson-Smith, 2007):

a. Adanya perasaan kesepian 
b. Kecemasan dalam waktu transisi, misalnya ketika memiliki anak pertama, anak memasuki usia remaja, anak telah memasuki usia dewasa, dan ketika memasuki masa pensiun.

c. Harapan-harapan perkawinan yang tidak tercapai, adanya visi dari kehidupan perkawinan yang kurang realistis.

d. Adanya gairah baru pada pasangan muda, sehingga menjadi semacam pelarian.

e. Kebutuhan yang besar akan perhatian

f. Adanya kesempatan untuk melakukan perselingkuhan, seperti kemudahan bertemu dengan lawan jenis misalnya di tempat kerja, hotel dan komunikasi yang mendukung untuk melakukan perselingkuhan.

g. Kebutuhan kehidupan seksual yang tidak dapat dipenuhi dalam perkawinan.

h. Ketidakhadiran pasangan secara fisik maupun emosional.

i. Perselingkuhan yang sering terjadi dalam keluarga besar, sehingga menyebabkan memudarkan nilai-nilai kesetiaan.

Perselingkuhan menimbulkan masalah yang serius dalam perkawinan, dan tidak sedikit yang kemudian berakhir dengan perceraian karena istri merasa sudah tidak sanggup untuk bertahan setelah mengetahui bahwa cinta mereka dikhianati dan suami berbagi keintiman dengan wanita lain. Pada saat istri mengetahui bahwa kepercayaan yang sudah diberikan secara penuh kemudian diselewengken oleh suami, para istri berubah menjadi sangat curiga (Glass, S. P. \& Staeheli, 2003).

Pasangan yang memutuskan untuk tetap mempertahankan perkawinan, dampak negatif perselingkuhan amat dirasakan oleh istri, sebagai pihak yang dikhianati, istri merasakan berbagai emosi negative secara intens dan kadang juga timbul gejala depresi. Akan timbul konflik dalam sebuah pilihan antara bertahan dikarenakan masih mencintai suami dan anak-anak, dengan ingin segera bercerai karena perbuatan suami telah melanggar prinsip utama dalam perkawinan (Snyder, D. K., Baucom, D. H., \& Gordon, 2008).

Tujuan penelitian melihat lebih dalam tentang dinamika resiliensi pada perempuan yang menjadi korban perselingkuhan, khususnya bagaimana para istri dapat bertahan dalam situasi konflik. Resiliensi adalah kapasitas untuk merespon secara sehat dan produktif ketika menghadapi kesulitan dan trauma, dimana hal ini penting untuk mengelola tekanan sehari-hari. Individu yang mempunyai resiliensi yang baik memahami bahwa kesalahan yang dilakukan bukan merupakan akhir. Individu mengambil makna dari kesalahan dan menggunakan pengetahuan untuk meraih sesuatu yang lebih tinggi.

Hasil penelitian yang dilakukan dapat menjadikan sebuah temuan yang baru berkaitan dengan resiliensi wanita yang mengalami perselingkuhan pada suami, selain itu bisa menjadi gambaran bagaimana self healing atau terapi yang bisa digali pada kasus wanita yang mengalami perselingkuhan pada suami. Beberapa penelitian sebelumnya yang mengangkat tema serupa memiliki resilensi yang berbeda dengan penelitian ini seperti faktor anak, faktor keyakinan kepada Tuhan, faktor finansial, maupun kekhawatiran judgment dari masyarakat untuk menyandang status janda. 


\section{Metode Penelitian}

Penelitian menggunakan model penelitian kualitatif studi kasus. Penelitian studi kasus merupakan pengujian secara rinci terhadap suatu data subjek atau satu tempat penyimpanan dokumen, atau satu peristiwa tertentu. Penelitian studi kasus meliputi antara lain (1) penelitiannya dapat berupa manusia, peristiwa, latar dan dokumen, (2) sasaran-sasarannya ditelaah secara mendalam sebagai suatu totalitas sesuai dengan latar atau konteksnya masing-masing dengan maksud untuk memahami berbagai kaitan yang ada di antara variabel-variabelnya (Bogdan dan Biklien, 1982).

Penelitian ini melibatkan 2 orang subjek yang tinggal di lbukota Jakarta sebagai korban dari Suami yang melakukan perselingkuhan. Selain itu karakter subjek dalam penelitian ini selain menjadi korban perselingkuhan suami, mereka juga mampu mempertahankan rumah tangganya selama lebih dari 20 tahun dari waktu perselingkuhan terjadi. Keadaan sakit hati, jengkel, kecewa, dan tindakan agresif mampu dikalahkan dan memilih untuk bertahan dalam situasi yang penuh dengan kesulitan. Jenis perselingkuhan yang terjadi pada suami dua responden adalah "Romantic Love Affair" yaitu perselingkuhan tipe ini melibatkan hubungan emosional yang dalam. Hubungan menjadi sangat penting sekali khususnya dalam kehidupan pasangan

Instrumen pokok dalam penelitian ini adalah peneliti sendiri, peneliti sebagai instrument dapat berhubungan langsung dengan responden dan mampu memahami serta menilai berbagai bentuk dari interaksi di lapangan. Instrumen kedua dalam penelitian ini adalah dengan metode wawancara. Secara umum, penyusunan instrumen pengumpulan data berupa pedoman wawancara dilakukan dengan beberapa tahap.Instrumen ketiga dalam penelitian ini adalah observasi.

Untuk memperoleh data yang digunakan dalam penelitian, teknik yang akan digunakan peneliti adalah sebagai berikut :

1. Wawancara Mendalam (Indepth Interview)

Teknik wawancara mendalam ini diperoleh langsunng dari subjek penelitian melalui serangkaian tanya jawab dengan pihak-pihak yang terkait dengan pokok permasalahan. Penelitian ini menggunakan pedoman wawancara yang sudah disusun sedemikan rupa berkaitan dengan pokok kasus yang sedang diteliti.

2. Observasi

observasi adalah kemampuan seseorang untuk menggunakan pengamatannya melalui hasil kerja dari penginderaan. Observasi dilakukan dengan model nonpartisipan, dimana peneliti tidak ikut serta dalam kegiatan-kegiatan yang subjek lakukan (Burhan, 2007).

Tahapan pertama dalam penelitian ini adalah pemilihan tema diikuti dengan mencari literatur dan dikumpulkan dipisahkan pada bagian-bagian yang mempunyai relevansi dengan topik penelitian yang sedang dikaji. Berikutnya fokus pada permasalahan penelitian, setelah itu dilakukan pengumpulan data dengan teknik wawancara dan observasi, setelah data terkumpul dengan cukup maka dilakukan analisis data untuk dengan cara pengkodean dan juga 
pemaknaan. Kemudian pembuatan laporan didasarkan atas data-data yang sudah ditemukan di lapangan.

\section{Hasil dan Pembahasan}

Pada bagian ini, peneliti akan menganalisis tema-tema berdasarkan eksplikasi tematema yang muncul pada masing-masing responden penelitian. Analisis tematik ini didahului dengan deskripsi pengalaman yang dialami oleh responden, kemudian masuk dalam dinamika resiliensi pada responden yang menjadi korban perselingkuhan suaminya

\subsection{Responden penelitian 1}

Subjek pertama kali mengetahui perselingkuhan suaminya yaitu ketika melihat pesan yang ada di smartphone suaminya yang berisi obrolan dengan seorang wanita.

"awal-awalnya kan saya ngelihat chat an itu kok perempuan itu kirim foto yang agak vulgar, hampir-hampir terlihat dadanya, loh kok berteman kek gini, kemudian saya balesin" (MD, 9496)

Responden penelitian mencurigai perilaku suaminya karena kalimat-kalimat di dalam obrolan pesan di smartphone mengandung unsur-unsur yang sudah melewati batas orang dalam berumah tangga. Putri responden juga mengetahui melalui pesan smartphone dari suami responden, di dalam aplikasi pesan tersimpan foto-foto mesra suami responden dengan perempuan lain. Ketika anak dari responden mengetahui foto-foto mesra dari suami responden, suami responden marah dan menolak mengakui bahwa yang bersangkutan melakukan perselingkuhan.

"oh bapaknya marah kayak apa ya ngancam saya awas kamu begini-begini. Orang namanya, namanya Sukarti bu, Sukarti itu gak ngapa ngapain, kamu tuh ga usah celamitan megang-megang hp saya, sama saya udah" (MD, 109-112).

Beberapa kejadian-kejadian yang terjadi pada responden berkaitan dengan suaminya menyiratkan adanya fenomena perselingkuhan yang terjadi pada suaminya. Ketika diketahui bahwa suami dari responden melakukan perselingkuhan, sering terjadi pertengkaran di dalam keluarga dari subjek, tetapi subjek lebih sering menghindarinya mengingat ada keluarga di dalam rumah. Perselingkuhan suami responden tidak hanya dengan 1 orang, tetapi suami responden melakukan perselingkuhan dengan beberapa orang wanita yang dikenalnya. Beberapa kali kejadian perselingkuhan juga difoto oleh suami responden dan diketahui oleh istri responden

"Kemarin saya pulang kampung, pulang kampung saking stresnya, trus pas pulang itu gak sengaja juga, bapak saya kan belum sakit pulang tuh cuman masuk angin biasa trus pas itu curhat ke mak saya" (MD 151-155)

Kejadian-kejadian perselingkuhan yang dialami suami responden, sempat membuat respoden stress berat. Ketika stress berat, responden biasanya pulang ke rumah orang tua yang berada di Jawa Tengah. Ketika pulang ke rumah responden curhat dengan orang tua berkaitan dengan perilaku suami dari responden. Responden mengaku biasanya ayah dari responden tidak percaya dengan karakter dari suami, tetapi pernah suatu ketika ayah dari responden melakukan 
pembelaan terhadap responden. Responden juga mengakui bahwa Ayahnya tiba-tiba sakit ketika mendengar berita bahwa suami responden diketahui melakukan perselingkuhan.

Kebetulan setelah peristiwa reponden pulang karena stres menghadapi perilaku dari suami, ayah dari responden jatuh sakit dan harus rawat inap di rumah sakit, dan dalam waktu semalam setelah di rawat di rumah sakit kemudian ayah dari responden meninggal dunia. Pada saat itu pula suami dari responden masih berbohong mengenai keberadaannya yang sesungguhnya. Pada fenomena-fenomena yang ditemui responden, suami dari responden sering mengungkapkan kebohongan.

Perselingkuhan Suami dari responden tidak hanya terjadi sekali dalam artian tidak hanya melakukan perselingkuhan dengan satu wanita saja. Beberapa wanita pernah menjadi korban dari suami responden dari Ibu X. Bahkan perselingkuhan itu terjadi sudah lama semenjak reponden mengandung buah hati yang pertama, dan ketahuan ketika buah hati sudah menginjak umur 40 bulan sampai dengan genap 5 tahun.

"Itu masih berlanjut itu masih sms itu berlanjut terus sampai Afikah umur 5 tahun kan darin Afikah umur 40 hari ampe Afikah umur 5 tahun masih kayak gitu terus. Eh terus saya lihat hp bapaknya. Umur 40 bulan, eh 40 hari habis lahiran saya sampai Afikah umur 5 tahun itu selesaianya" (MD, 171-176).

Melihat fenomena yang terjadi bahwa perselingkuhan dari suami responden terjadi berulang kali, pada saat tertentu responden timbul keinginan untuk mengakhiri rumah tangganya dalam artian mengajukan perceraian kepada suaminya. Tetapi kadang ada beberapa temanteman dari responden yang memberikan nasihat untuk mengurungkan keputusan tersebut, dikarenakan masih ada beban anak-anak dari responden yang membutuhkan figur orang tua yang lengkap di dalam keluarga.

"Tapi temen-temen saya pada bilangin, jangan gitu kasihan anak-anakmu, apalagi yang kecil kan psikisnya, nanti yang paling kecil gimana? Namun saya tetep kekeh nggak ah gak mau biarin nanti maksudnya. Kalau anak ya nanti nyariin ibunya, saya yang tentrem itu yang kecil diurusin sama adik saya. Adik saya kan belum punya anak, saya tenangnya disitu“ (MD, 255-261).

Di dalam stress dan kesedihan yang dialami oleh respoden penelitian, responden kadang menghibur diri dengan cara bernostalgia dengan masa lalu ketika belum menikah. Beberapa kali masa pacaran yang dialami responden menjadi memori kadang menjadi penghibur ketika sedang mengalami stress yang diakibatkan tingkah laku dari suami.

"Saya itu kan ama mantanku waktu masih sekolah gitu, sama mantan saya kakak kelas saya. Dia bilang, dia kan mau nyium saya cuman dia takut gitu. Aku mau nyentuh kamu ntar aja kalau udah jadi istri aku, kan kalau udah lulus kamu aku nikahin, udah kerja tetap aku nglamar kamu gitu" (MD, 288-294)

Responden menceritakan awal pertemuan dengan suami yang sekarang, pada masa awal perkenalan pernah ada rekan dari responden yang mengatakan bahwa untuk tidak menikah dengan suami yang sekarang, tetapi tidak menjelaskan maksud alasannya. Tetapi 
kebaikan hati atau perhatian yang ditunjukkan suami responden membuat responden tidak enak hati. Misalnya setiap gajian suami responden membawakan makanan kepada bersangkutan. Beberapa karakter yang muncul ketika berpecaran dengan suami yang sekarang adalah sifat posesif atau cemburu yang berlebihan, dan sampai saat ini tidak hilang. Pernah pada suatu saat suami dari responden berbuat kasar pada responden. Bebeberapa ancaman juga pernah dialami oleh responden ketika ada hal-hal yang dianggap mengganggu, misalnya ada pria lain yang menaruh perhatian.

Responden juga mengatakan beberapa kali akan dilamar pria, walapun dengan status pernikahan siri, tetapi responden menolak, karena yang bersangkutan masih masih mempunyai istri. Untuk menghilangkan sementara kesedihan karena perselingkuhan yang dilakukan suami, responden sering membayangkan menikah dengan suami bayangan, dalam artian suami imajiner yag diciptakan oleh responden. Hal itu dilakukan untuk mencari penghiburan karena permasalahan yang sedang dihadapi.

Responden juga berpikir kenapa yang bersangkutan bisa sangat mencintai suami, dan berpikir untuk menghilangkan perasaan "cinta" dari responden. Responden beberapa kali meminta bantuan ahli sprititual (kiai) dengan tujuan agar dapat mengurangi dan bahkan menghilangkan rasa cinta kepada suami.

"iya ke aku, terus kalau ada duit lebih saya minta apa dibeliin. Dia sebenernya perhatian sayang gitu Bu, yang bikin saya.. makanya saya mikirnya 'iya kalau ntar dapet suami kaya suami aku, kalau nggak?' juga kaya gitu Bu pikirannya tuh Bu. Jadi ketutup ya ? semua tadi yang pernah nyakitinlah yang pernah selingkuh tuh kayanya ketutup semua dengan sebenarnya kebaikan itu tadi ?" (MD 320-333).

Salah satu faktor yang diceritakan oleh responden kenapa yang bersangkutan tidak dapat melupakan rasa cinta suami adalah karena karakter suaminya yang sangat perhatian terhadap keluarga. Jadi hal yang terkait perilaku yang kurang baik yang telah dilakukan seakanakan tertutupi. Responden juga mengakui bahwa yang bersangkutan dikenal orang yang dermawan di kalangan teman-teman responden. Responden juga mengakui bahwa suami dari responden sangat perhatian pada anak-anaknya,

"Yang saya tahu kemarin sama.... orang Banyuwangi kayanya tuh dia apa, kaya.... dikasih apa dikasih.... apa ya Bu? Emmm yaa.... yang dagang ikan itu apa? Yang dagang ikan? apa itu? Apa yaa namanya... pokoknya itu tuh kaya ilmu gaib gitu loh, yang pokoknya yang adanya di ikan yang gede-gede itu loh.. apasi namanya?? Mustika.. Mustika ikan gitu". (MD 350-355).

Berkaitan dengan perasaan cinta kepada suami, responden mengatakan pernah mendapati peristiwa ketika bertemu dengan suaminya, yaitu diberi tahu bahwa ada bendabenda spiritual yang dipakai oleh suami responden dengan tujuan untuk pengasihan wanita. Ada perasaan kontradiktif yang terjadi berkaitan fenomena yang dialami oleh subjek. Responden mengaku kalau wajah dari suami tidak terlau menarik, tetapi dalam perasaan responden kelihatan sangat menarik. 


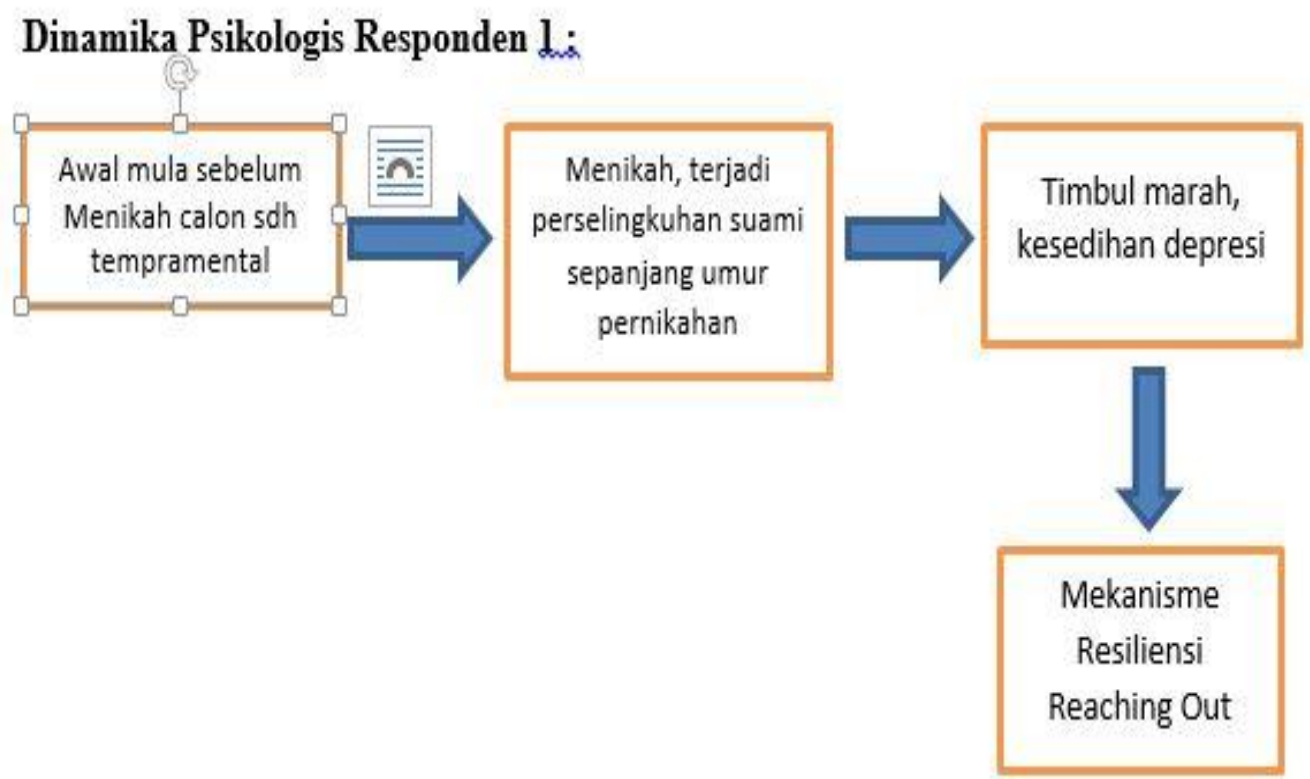

Sumber: Hasil Penelitian (2020)

Gambar 1. Dinamika Psikologis Responden 1

Sampai pada waktu terakhir terakhir peneliti mengambil data penelitian, suami yang bersangkutan masih sering diketahui melakukan perselingkuhan. Tetapi dalam pikiran responden ada keinginan bahwa pada suatu waktu suami akan melakukan pertobatan dan meminta maaf berkaitan dengan perilaku yang sudah dilakukan sejauh ini.

Gortberg (1995) menyatakan bahwa sumber resiliensi bisa dari diri sendiri yaitu I am, I can dan I have, yang diterjemahkan ketika seseorang memiliki sikap dan kepercayaan diri. Pada subjek 1 terlihat bahwa subjek berusaha meningkatkan kemampuan resiliensinya dengan berfokus pada penguatan konsep diri.

\subsection{Responden Penelitian 2}

Responden yang kedua sudah menjalani pernikahan selama 35 tahun. Sudah cukup panjang untuk usia pernikahan. Menjadi pernasalahan ketika pernikahan yang dijalani oleh responden 2 tidak seperti pernikahan ideal dimana membentuk keluarga yang harmonis dan bahagia. Responden menerangkan bahwa pada saat ini suami sedang menjalani pengobatan berkaitan dengan penyakit yang dideritanya.

Berdasarkan data dari responden, keterangan didapat bahwa dalam kesehariannya sering terjadi pertengkaran di dalam kehidupan rumah tangga. Suami dari responden sering marah ketika berhadapan dengan responden sebagai istrinya, mulai dari permasalahan yang kecil sampai besar.

"Emang dia hobi marahin saya tuh, saya mah udah terbiasa. Mesti, salah sedikit marah. Itu walaupun saya tetep manis dibilang saya.. itu tembakan saya. "Tembakan kamu Cuma air mata kan?” gitu. Apalagi yang gua harus ngomong gitu, masa gua nembak pake apaan? “ (MS 67-72). 
Pengakuan responden sering mendapat kekerasan verbal oleh suaminya. Seringnya dibandingkan dengan wanita lain membuat responden sering merasa sakit hati dengan suami yang bersangkutan. Selain itu responden juga sering dibentak-bentak oleh suami. Responden mengatakan bahwa suami sudah melakukan perselingkuhan ketika umur pernikahan menginjak umur 9 tahun. Pada saat itu suami responden bekerja di sebuah perusahaan yang ada di Jakarta Selatan. Perubahan perilaku suami respondenmuncul, misalnya ketika pulang dari kantor sering marah tanpa sebab dengan istri sebagai objek kemarahan. Responden mengetahui pertama kali suaminya mempunyai affair ketika ada acara dari kantor di suatu tempat, dan disitu responden sebagai pasangannya ikut di acara. Responden melihat bahwa suaminya sangat berbahagia ketika bertemu dengan salah satu teman wanita di acara tersebut. Disitulah muncul fakta bahwa suami yang bersangkutan mempunyai hubungan dengan seorang wanita.

Di dalam acara kantor dari suami, responden merasa ada perubahan dalam diri suami, karakter suami menjadi sangat dingin dan mengabaikan istri. Responden merasa sangat tidak dihargai sebagai istri yang bersangkutan. Teman-teman dari suami responden juga mengatakan bahwa suaminya sering jalan dan terlihat akrab dengan perempuan tersebut. Responden juga melihat keanehan yang terjadi pada perilaku suaminya. Responden mengaku bahwa setelah mengenal perempuan itu mengenal suaminya, suaminya sering pulang malam. Tetapi ketika diklarifikasi terkait dengan kenapa sering pulang malam, suami beralasan bahwa sering ada tugas kantor.

"Tiap pulang kantor jam 11 malem, setengah 12 malem, tiap pulang setiap hari kaya gitu. Alesannya ngomong.. ngobyek kantor, kerjaan kantor banyak. Kita iyain aja. Yang penting gua dapet duit kan gitu kan. Nanti dia digunain lah ama perempuan itu. dia bilang kalo nganter jemput tuh, karena rumah dia di Bekasi jadi sekalian kerumah orang tuanya di Bekasi, jadi bisa nganter si perempuan. Kan aneh, di Bekasi rumahnya? Dibilang orang kantor" (MS 110116)

Setelah responden mengetahui bahwa suaminya berselingkuh, perilaku suami kepada responden menjadi berubah drastis, mulai dari tidak mau untuk disiapkan makanan, tidak mau tidur dalam satu ranjang, sampai-sampai sang suami tidak mau pulang ke rumah istri. Pada saat itu responden mengaku sering pingsan karena permasalahan yang dihadapi.

Semenjak mengenal perempuan yang menjadi selingkuhannya sangat sering kali suami responden mengeluarkan kata-kata makian yang ditujukan pada responden. Kekerasan secara verbal yang diterima suami responden, membuat orangtua responden menasehati untuk tidak lagi melanjutkan hubungan pernikahan dalam artian bercerai. Bahkan ketika makan keluar keluarga, responden sebagai istri dilarang untuk duduk semeja oleh suaminya. Sebagai istri responden tidak boleh mengetahui penghasilan sebenarnya dari sang suami. Jadi kadang penghasilan yang diberikan kurang untuk memenuhi kebutuhan rumah tangga dari responden, jadi kadang responden menggadai barang untuk memenuhi kebutuhan sehari hari yang kurang. "kamu ngapain mau tahu gaji saya berapa, yang kerja saya bukan kamu" dia pasti gitu kalo ngomong. Kadang yaudahlah, turutin aja apa kata dia. Sampe anak-anak kuliah yang bayar 
semua dia. Ya sehari-hari bisanya kita aja. Kadang ada sodara yang ngasih ke saya kan. Kadang sodaranya dia yang pada ngerti tuh pada ngasih." (MS, 278-283)

Responden juga bercerita awal pertemjuannya dengan suaminya. Bahwa menurut orang-orang suaminya mempunyai muka yang kurang ramah, dan juga terkenal dengan sikapnya yang temperamental pada orang lain. Sampai pada saat ada beberapa rekan dari responden terheran-heran kenapa responden mau berhubungan dengan suaminya yang sekarang karena suami yang bersangkutan terkenal dengan sikapnya yang temperamental.

Pada akhirnya seperti responden yang pertama walaupun responden sudah sering mendapatkan agresi secara verbal maupun perilaku, responden tetap memberikan dukungan kepada suami agar dapat berubah dan kembali menjadi suami yang baik untuk istrinya. Responden sering mendoakan supaya hal itu terjadi.

\section{Dinamika psikologis Responden 2}

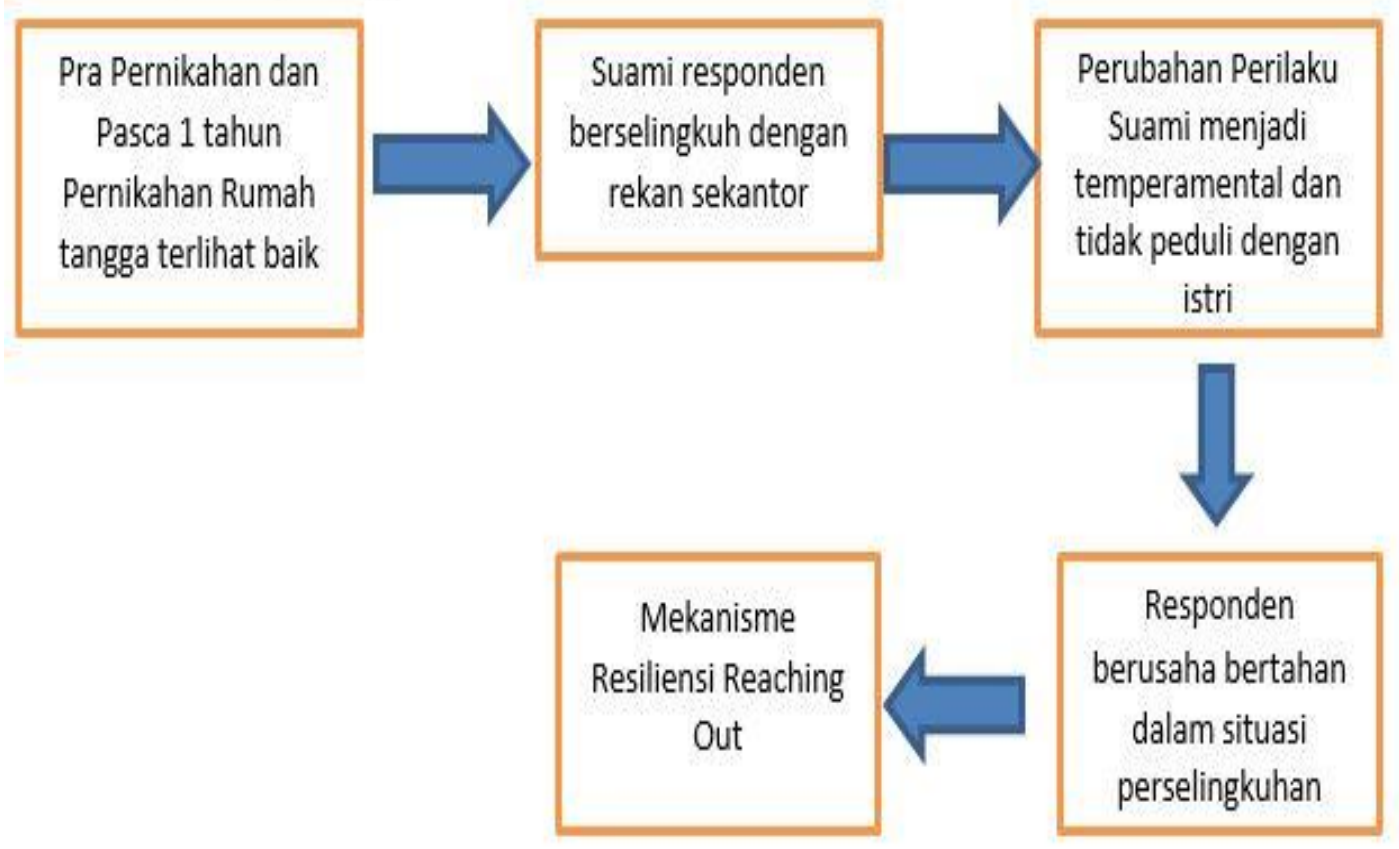

Sumber: Hasil Penelitian (2020)

Gambar 2. Dinamika Psikologis Responden 2

Kesimpulan utama yang didapat dari penelitian ini adalah banyak individu yang tidak mampu melakukan reaching out, hal ini dikarenakan mereka telah diajarkan sejak kecil untuk sedapat mungkin menghindari kegagalan dan situasi yang memalukan. Mereka adalah individuindividu yang lebih memilih memiliki kehidupan standart dibandingkan harus meraih kesuksesan, namun harus berhadapan dengan resiko kegagalan hidup dan hinaan masyarakat. Hal ini menunjukkan kecenderungan individu untuk berlebih-lebihan (overestimate) dalam memandang kemungkinan hal-hal buruk yang dapat terjadi dimasa mendatang (Revich, K, \& Shatte, A.2002)

Penyesuaian peran seksual pada masa dewasa awal benar-benar sulit. Jauh sebelum masa remaja berakhir, anak laki-laki dan perempuan telah menyadari pembagian peran seks 
yang direstui masyarakat, namun belum tentu mereka mau menerima sepenuhnya. Pencapaian kepuasan hubungan (resmi atau sembunyi-sembunyi) terdapat kebutuhan yang juga menjadi aspek kepuasan yang harus dipenuhi agar perkawinan memiliki kepuasan, yaitu kebutuhan materiil (biologis) kebutuhan seksual dan kebutuhan psikologis (Hurloc, 1994).

Kepuasan dalam kebutuhan materiil ditandai dengan adanhya kepuasan fisik atau atau biologis atas pemenuhan kebutuhan berupa makanan, tempat tinggal, keadaan rumah tangga yang teratur dan uang. Walster and Walster (1978) menjelaskan berkaitan dengan penelitiannya tentang pasangan yang harmonis. Beberapa aspek yang dimiliki pasangan yang puas antara lain; ramah, santai, pintar mampu menjadi sumber informasi, penampilan fisik yang atraktif dan memperhatikan penampilan fisik seperti, serta mampu menunjukkan pada pasangan, memahami pasangan dan peduli pada kebutuhan-kebutuhan emosional; menunjukkan apresiasi pada pasangan, menujukkan kasih sayang seperti menyentuh, memeluk, dan mencium, berpartisipasi aktif dan penuh dengan interaksi seksual, menghormati kebebasan pasangan dan merupakan individu yang mandiri, menikmati kehidupan sehari-hari, memiliki rasa humor dan tidak pemurung, menjadi rekan yang baik, memberikan saran dan ide-ide menarik, saling menceritakan tentang kejadian hari itu, tertarik dan bersedia menjadi pendengar yang baik. Memiliki kecocokan dengan teman keluarga dan pasangan. Beberapa permasalahan sering terjadi di dalam hubungan pernikahan, bahwa ada hal-hal yang bersifat emosional yang tidak dapat ditemui dalam diri pasangannya, sehingga terkadang seorang suami mencari hiburan di luar rumah(Walster.E \& Walster, 1978).

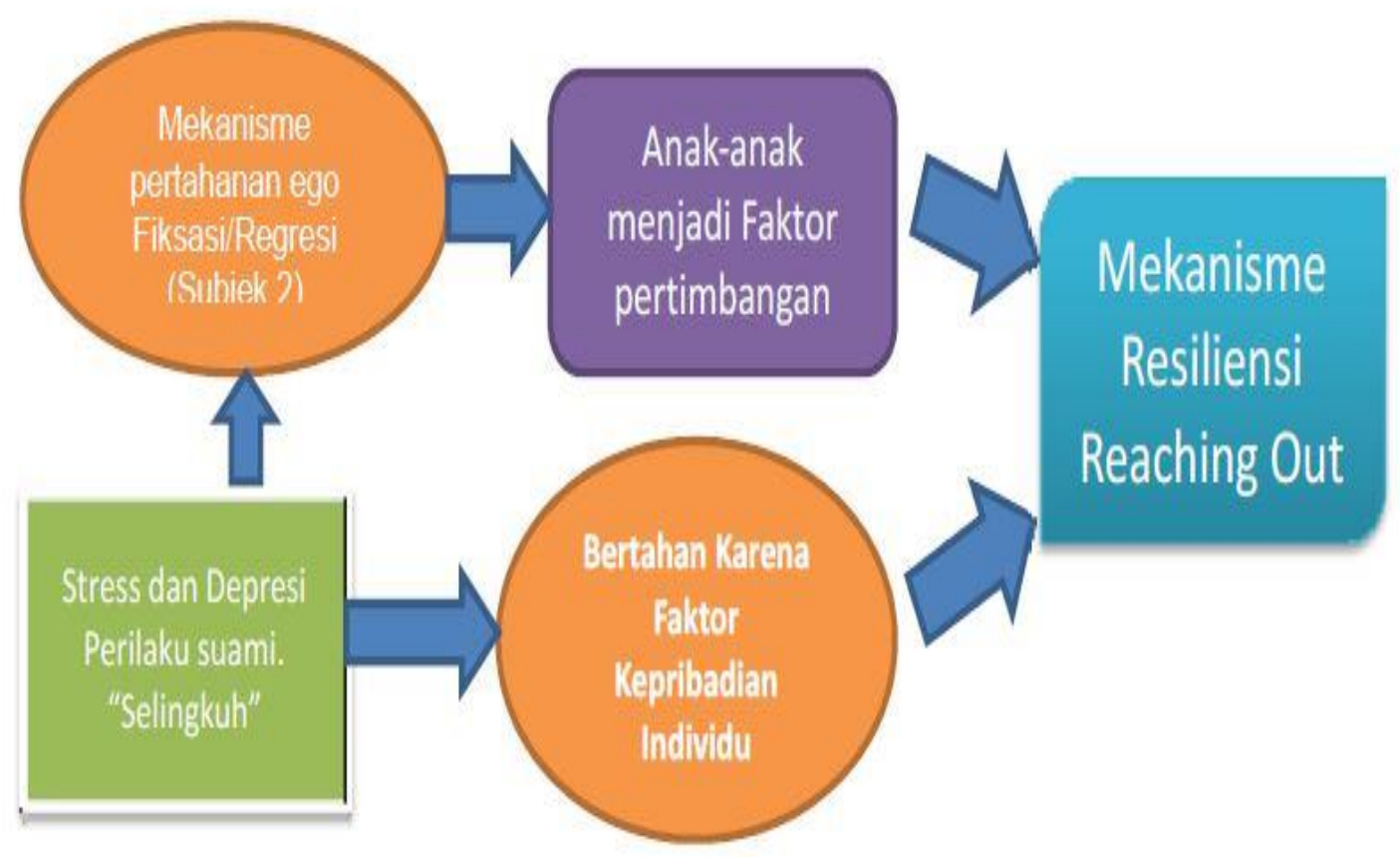

Sumber: Hasil Penelitian (2020)

Gambar 3. Dinamika Resiliensi Pada Subjek 
Resiliensi merupakan bagaimana cara individu bertahan dalam kondisi psikologis yang tertekan. Melihat fenomena permasalahan rumah tangga yang terjadi, ada kesamaan pola di kedua responden bahwa sebelum pernikahan ada beberapa orang di sekitar yang mengingatkan untuk tidak menikah dengan pasangan yang sekarang. Perbedaan perlakukan suami kedua responden terletak pada perilaku suami masing masing. Responden A mengungkap fakta bahwa walaupun suaminya melakukan perselingkuhan, suaminya adalah suami yang sangat baik dan perhatian pada istri dan anak-anaknya, sehingga rasa cinta pada diri responden juga besar. Berbeda dengan dinamika pada responden $\mathrm{B}$, responden sering mendapati kekerasan secara verbal dari suaminya, sehingga pernikahan yang dijalani selama ini hanya sebagai formalitas belaka.

\section{Kesimpulan}

Menjadi pertanyaan kenapa dengan peristiwa perselingkuhan yang terjadi responden masih tetap mempertahankan rumah tangga. Untuk responden A berpikir bahwa kelangsungan rumah tangga harus tetap dijaga demi kelangsungan masa depan anak. Berbeda dengan responden $B$ yang menurut peneliti adalah tipe perempuan yang setia. Responden $B$ cenderung memiliki kepribadian/sifat pasif, dengan perilaku ini responden B tidak terlalu berpikir mendalam berkaitan dengan perilaku yang sudah dilakukan suami yaitu berselingkuh. Kesamaan yang muncul dari dua subjek penelitian adalah mereka cenderung berpikir berkaitan masa depan keluara khususnya anak, sehingga cenderung mempertahankan rumah tangga. Keduanya juga memiliki kemampuan untuk mengatasi "kemalangan" dan bangkit dari keterpurukan dan meraih aspek positif dari keterpurukannya tersebut. Tahapan yang ditemukan berkaitan dengan resiliensi pada kedua subjek adalah "mengalah" sesuai yang dikatakan O'Leary dan Ickovics(Coulson, 2006) salah satu tahapan ketika orang menghadapi kondisi yang menekan adalah "mengalah". Mengalah yaitu kondisi individu mengalah atau menyerah menghadapi suatu keadaan yang menekan. Pada level ini adalah kondisi dimana individu menemukan dan mengalami sebuah permasalahan yang berat. Resiliensi pada subjek pertama terjadi karena rasa cinta yang besar kepada suami subjek, walaupun suaminya melalukan perselingkuhan, perilaku perhatian dan kasih sayang pada subjek penelitian 1 tidak berkurang sedikitpun, hal ini yang membuat subjek tetap mempertahankan rumah tangga dengan suami. Hal ini berbeda dengan subjek yang kedua, subjek yang kedua adalah tipe perempuan yang sederhana dan mempunyai karakter yang kuat, sehingga acuannya adalah bagaimana rumah tangga tetap utuh, walaupun pada kenyatannya banyak permasalahan yang terjadi. Selain dari faktor karakter individu ada juga external Protective Factor yang merupakan faktor protektif yang bersumber dari luar individu, misalnya suport dari keluarga dan lingkungan. 


\section{Ucapan Terima Kasih (Opsional)}

Terima kasih kami sampaikan pada pihak yang sudah memberikan dukungan dalam penyelesaian penelitian ini khususnya subjek penelitian, yang telah memberikan kesempatan kami dalam proses pengambilan data.

\section{Daftar Pustaka}

Amacon. Reivich, K., \& Shatte, A. (2002). No TitleThe Resilience Factor: 7 Keys To Finding Your Inner Strength And Overcome Life's Hurdles. Retrieved from https://www.amazon.com/Resilience-Factor-Finding-Strength-Overcoming/dp/0767911911

Burhan, B. (2007). Penelitian Kualitatif: Komunikasi, Ekonomi, Kebijakan Publik dan IImu Sosial lainnya. Jakarta: Putra Grafika.

Catatan Tahunan (CATAHU) Komnas Perempuan Tahun. Tergerusnya Ruang Aman Perempuan dalam Pusaran Politik Populisme. , (2018).

Coulson, R. (2006). Resilience and self-talk in university students (University of Calgary). https://doi.org/. doi:10.11575/PRISM/1047

Eaves, S. H., \& Robertson-Smith, M. (2007). The relationship between self-worth and marital infidelity: A pilot study. The Family Journal: Counseling and Therapy for Couples and Families, 15(4), 382-386.

Fernanda Rojas, L. (2015). Factors affecting academic resilience in middle school students: A case study. Gist Education And Learning Research Journal, 11(11), 63-78.

Glass, S. P. \& Staeheli, J. C. (2003). Not "just friends". Rebuilding trust and recovering your sanity after infidelity. New York: Free Press.

Grotberg, E. H. (1995). A guide to promoting resiliency in children: Strengthening the human spirit. In Early Chidhood Development: Practice And Reflections.

Henderson, N. Dan Milstein, M. M. (2003). Resiliency in schools. Making it happen for students and educators. California.: Corwin Press: Inc.

Herrman, H., Stewart, D. E., Diaz-Granados, N., Berger, E. L., Jackson, B., \& Yuen, T. (2011). What is resilience? Can Jpsychiatry, 56(5), 258-265.

Santrock, J. W. (2002). Life-span Development Perkembangan Masa Hidup Edisi Kelima. Jakarta: Erlangga.

Schoon, I. (2006). Risk and resilience: adaptations in changing times first edition. United Kingdom,. New York: Cambridge University Press.

Snyder, D. K., Baucom, D. H., \& Gordon, K. C. (2008). An Integrative Approach to Treating Infidelity. The Family Journal, 16(4), 300-307.

Spring, J. A. (2012). After the Affair: Healing the Pain and Rebuilding Trust When a Partner Has Been Unfaithful. New York: Harper Collins.

Subotnik, R.B., \& Harris, G. . (2005). Surviving infidelity: Making decisions, recovering from the pain. Avon: Adams Media.

Walster.E \& Walster, G. W. (1978). Equity and Premarital Sex. Journal of Personality and Social 
Psychology, 36(3), 82-92.

Widayanti. (2014). Faktor-Faktor Penyebab Perceraian Pada Keluarga Tenaga Kerja Wanita (TKW) Di Desa Citembong, Kecamatan Bantarsari, Kabupaten Cilacap. Universitas Negeri Yogyakarta. 